\title{
The concept of immune surveillance against tumors: The first theories
}

\author{
Domenico Ribatti ${ }^{1,2}$ \\ ${ }^{1}$ Department of Basic Medical Sciences, Neurosciences and Sensory Organs, University of Bari Medical School, Bari, Italy \\ 2 National Cancer Institute "Giovanni Paolo II", Bari, Italy \\ Correspondence to: Domenico Ribatti, email: domenico.ribatti@uniba.it
}

Keywords: Antigen; immune surveillance; history of medicine; T cell; tumor

Received: July 18, $2016 \quad$ Accepted: October 10, $2016 \quad$ Published: October 18, 2016

\section{ABSTRACT}

The immune system plays a major role in the surveillance against tumors. To avoid attack from the immune system, tumor cells develop different strategies to escape immune surveillance. Evidence of immune surveillance comes from both animal models and clinical observations. Mice with a wide variety of immunodeficiencies have a high rate of tumor incidence and are more susceptible to transplanted or chemical carcinogen-induced tumors. Immunosuppressed patients have a high incidence of tumors. However, many patients develop cancer even in the presence of an apparently normal immune system. This indicates that tumor cells are able to escape immune surveillance. The aim of this review article is to summarize the literature concerning the development of the theory of immune surveillance against tumors; to discuss the evidence for and against this theory, and to discuss the concept of immunoediting. Finally, the current approaches in anti-tumor immunotherapy will be analyzed.

\section{INTRODUCTION}

In 1909, Paul Ehrlich (Figure 1) formulated the hypothesis that host defense may prevent neoplastic cells from developing into tumors [1]. He stated that: "in the enormously complicated course of fetal and post-fetal development, aberrant cells become unusually common. Fortunately, in the majority of people, they remain completely latent thanks to the organism's positive mechanisms." [1]. This hypothesis was not proven experimentally at the time due to the inadequacy of experimental tools and knowledge.

Later, some biologists suggest the existence of an "immunological surveillance mechanism" against tumor cells. Lewis Thomas (Figure 2) suggested that the immune system recognize newly arising tumors through the expression of tumor specific neo-antigens on tumor cells and eliminate them, similarly to homograft rejection, maintaining tissue homeostasis in complex multicellular organism [2]. The first clear demonstration of specific capability to stimulate an immune response was made by Gross in 1953 after intradermal immunization of C3H mice, obtained by continuous brother to sister mating for more 20 years, against a sarcoma [3], followed by Foley in 1953 in methylcholantrene-induced tumors [4].

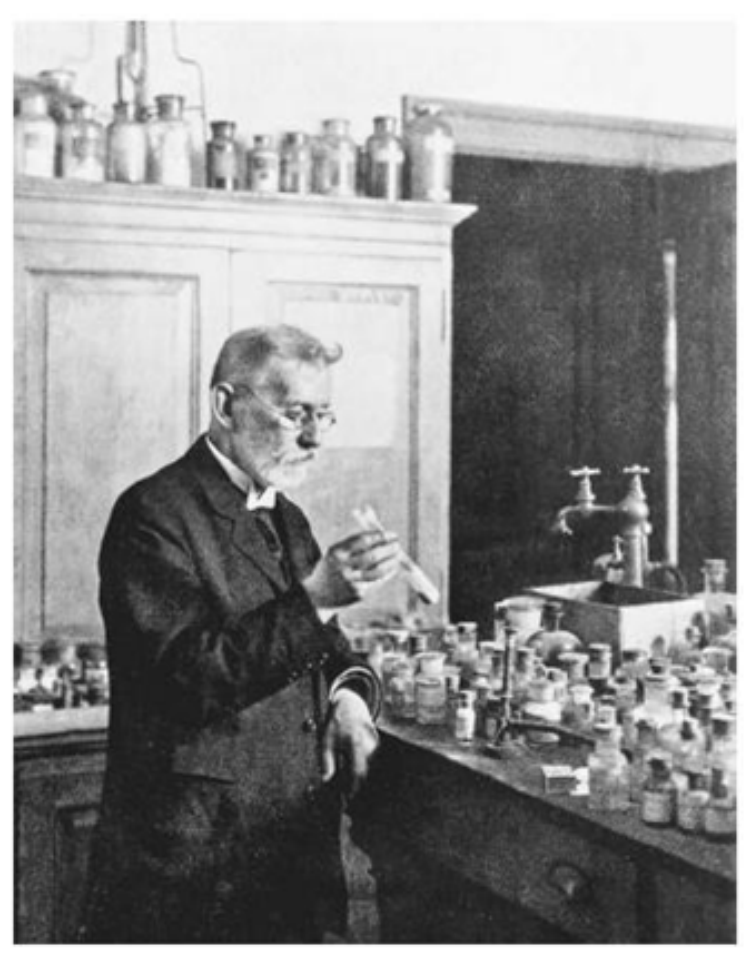

Figure 1: A portrait of Paul Ehrlich. 
Sir Frank Mac Farlane Burnet (Figure 3) hypothesize that tumor cell neo-antigens induce an immunological reaction against cancer and subsequently formulated the immune surveillance theory $[5,6]$. He wrote that: "It is by no means inconceivable that small accumulation of tumor cells may develop and because of their possession of new antigenic potentialities provoke an effective immunological reaction with regression of the tumor and no clinical hint of its existence." [6].

\section{EVIDENCES CONFIRMING THE THEORY OF IMMUNE SURVEILLANCE}

In transplantation models, tumors are rejected in syngeneic hosts, while transplantation of normal tissues are accepted, confirming the existence of tumor-specific antigens [6].

Professional antigen presenting cells process and present tumor associated antigens (via cross presentation of debris, perhaps due to spontaneous tumor cell lysis, or perhaps due to natural killer (NK) cell destruction, or other processes such as "nibbling") to immune cells, and generate memory and effector cells which survey the body, seeking out tumor cells. In different types of human tumors, including melanoma, cancer of breast, bladder, colon, prostate, ovary, rectum, and glioblastoma [713], a longer survival has been observed in patients with an higher number of lymphocytes and NK cells . These latter do not require prior sensitization for efficient tumor cell lysis and following activation with interleukin-2 (IL-2), NK cells can kill tumor cells [15].Regulatory T cells (Tregs) exert both detrimental and beneficial effects

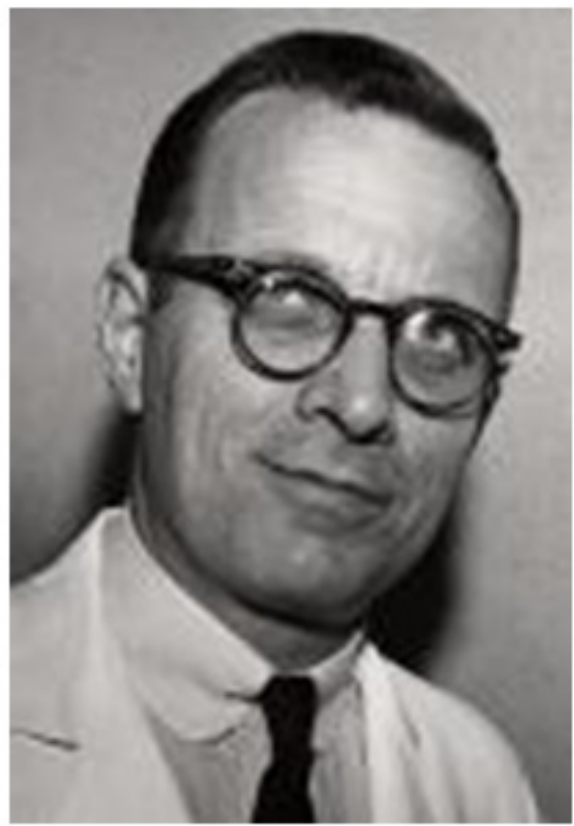

Figure 2:A portrait of Lewis Thomas. to the host $[16,17]$. Tumor antigens can be recognized by $\mathrm{T}$ cells, in cooperation with major histocompatibility complex (MHC) allowing $\mathrm{T}$ cells to interact with the antigen presenting cells [18].

\section{EVIDENCES AGAINST THE THEORY OF IMMUNE SURVEILLANCE}

Athymic nude mice, traditionally considered to lack T cells, did not develop significantly more spontaneous or methylcholantrene-induced tumors than control mice $[19,20]$. In this experimental condition, the immune response mediated by $\mathrm{T}$ and $\mathrm{NK}$ cells was similar in immunocompetent and nude mice. Interferon gamma (IFN $\gamma$ ) and perforin, are both involved in prevent tumor formation in mice $[21,22]$. In fact, neutralization of IFN $\gamma$ resulted in rapid growth of tumors [23], and mice lacking IFN $\gamma$ were more sensitive to methylcholantherene-induced carcinogenesis [21]. However, treatment with IFN $\gamma$ had no benefit for patients with different type of tumors [24-26]. Perforin inhibited B cell lymphoma development [27-29]. Moreover, mutations in the gene encoding perforin, have been demonstrated in lymphoma patients [30].

About $5 \%$ of individuals with primary or secondary immunodeficiences and individuals subjected to therapy to prevent transplant rejection present a heightened incidence of cancer [31]. Cancers most commonly found in immunodeficient individuals are virus-associated [32], including Epstein-Barr virus-related tumors [33, 34]. Failure of human herpes virus (HHV) immune response is one of the factors involved in the pathogenesis of Kaposi sarcoma [35]. Several other cancers, have increased

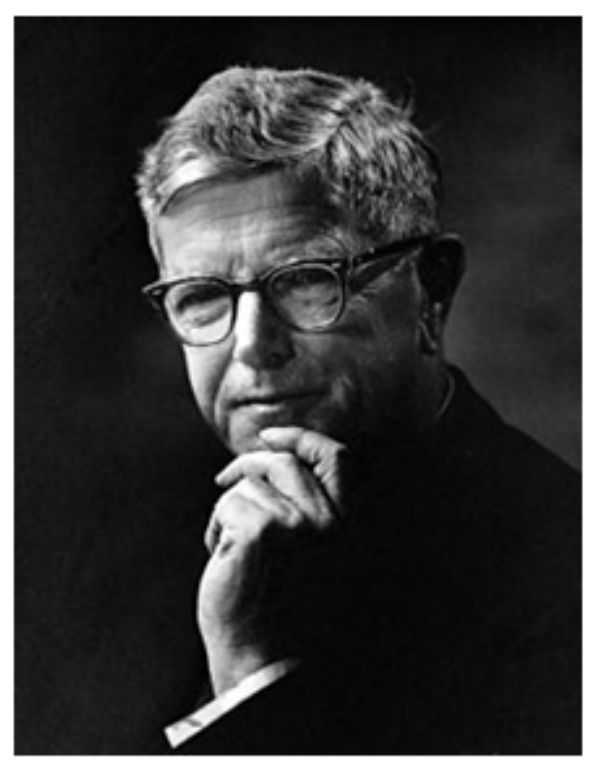

Figure 3: A portrait of Frank MacFarlane Burnet. 
incidences in persons with human immunodeficiency virus (HIV)/AIDS, including hepatocellular carcinoma, which is frequently associated with infection with the hepatitis B or $C$ virus [36]. Merkel cell carcinoma, a rare skin cancer that occurs more frequently after organ transplantation or B-cell malignancy, conditions of suppressed or disordered immunity, has an increased incidence in HIV-infected individuals [37].

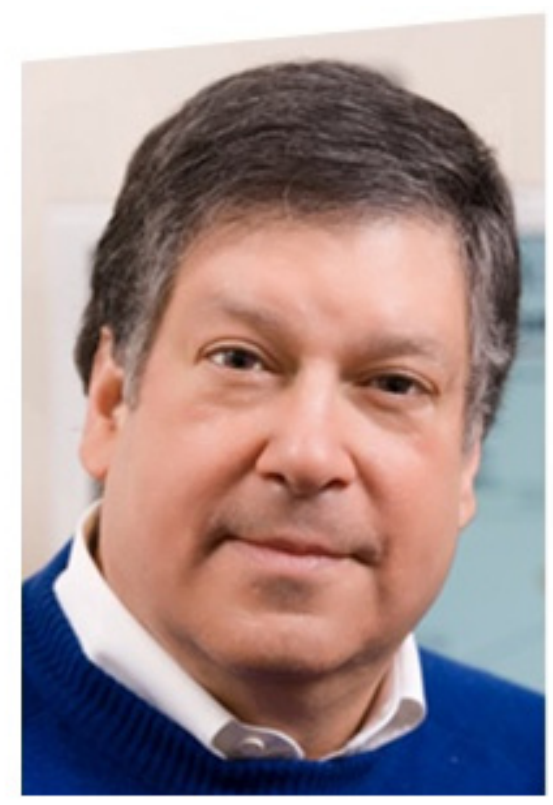

Figure 4: A portrait of Robert D. Schreiber.
Associations between different bacteria, including Helicobacter pylori and clamyidia, and higher incidence of various tumors have been described [38, 39]. Bacteria are capable of homing to tumors when systemically administered, resulting in high levels of replication locally $[40,41]$. However, the frequency of non-virally induced tumors, is not increased among transplant recipients [42].

Immune competence decreases with age, the socalled "immunosenescence", implying that decreased immunosurveillance against cancer contribute to increased disease in the elderly [43]. Cytomegalovirus (CMV) and Epstein Barr Virus (EBV) infection are determinants of immunosenescence [44].

Immunosuppression may be not associated to an increase of tumors $[45,46]$. In fact, thymectomy at birth reduced the incidence of mammary adenocarcinoma [47], and immunologic reconstitution restored the susceptibility to tumor [46]. The incidence of mammary carcinomas decreases in immunosuppressed individuals [48]. Finally, leprosy and sarcoidosis which are characterized by immunosuppression, are not associated to an increased incidence of tumors [49].

\section{IMMUNOEDITING, A NEW APPROACH}

As Sirvastava [50] said: "The immune surveillance hypothesis is often regarded as the intellectual underpinning of cancer immunology. Although the hypothesis itself has contributed little to our attempts to treat cancer through immunological means, it has

\title{
PROTAGONISTS OF RESEARCH IN TUMOR IMMUNOLOGY
}

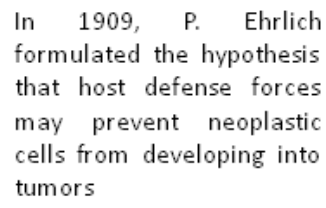

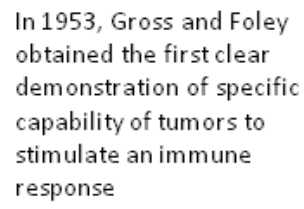

In 1953, Gross and Foley obtained the first clear demonstration of specific capability of tumors to stimulate an immune response

In the late $1950 \mathrm{~s}, \mathrm{~L}$. Thomas introduced and F. MacFarlane Burnet further developed the theory of immune surveillance
In 2002, R. D. Schreiber developed the

concept of immunoediting

\author{
MILESTONESIN IMMUNOTHERAPY OF TUMORS \\ 1984. Basic immunotherapy with IL-2 \\ 1988. Adoptive T-cell therapy (ACT) \\ 1996. DNA-vaccines \\ 1997. Antibody therapy \\ 2012. Dendritic cell vaccines
}

Figure 5: Time sheet of the protagonists of research in tumor immunology and of the milestones in immunotherapy of tumors. 
profound implications for understanding the functions of the immune system."

Dunn and Schreiber (Figure 4) developed the concept of "cancer immunoediting", composed of three phases [51]. In the first one, the elimination phase, tumor cells are killed by $\mathrm{NK}, \mathrm{CD}^{+}$and $\mathrm{CD}^{+}$cells [52]. The second phase corresponds to a state of equilibrium between immune and tumor cells. When the immune system is unable to destroy the tumor, the third phase, corresponding to the escape phase, develops which concludes with the appearance of clinically detectable tumors.

Multiple myeloma progresses from the monoclonal gammopathy of undetermined significance (MGUS) to asymptomatic and, respectively, symptomatic myeloma [53]. In this context, it is possible demonstrate that $\mathrm{T}$ cells from patients with MGUS develop an immune reaction to premalignant cells, which instead is absent in patients with multiple myeloma and the transition to multiple myeloma correspond to tumor escape phase [54].

The escape phase is characterized by the selection of tumor variants which will progress later on [55-57]; by a down-regulation or loss of the expression of tumor antigens; by an upregulation of resistance against tumor cells and/or an increased expression of pro-survival genes, and finally by the development of an immunouppressive tumor microenvironment [58]. Moreover, the establishment of a condition of central and peripheral immune tolerance, involving the activation of Tregs is crucial for the establishment of an escape mechanism [58, 59].

\section{CURRENT APPROACHES IN ANTI- TUMOR IMMUNOTHERAPY}

Some analysts have predicted that within ten years, immunotherapy will constitute $60 \%$ of all cancer treatments [60]. A novel group of immunomodulatory antibodies has been introduced in the clinical use, which can break tumor specific immune tolerance and induce regression of tumors. These antibodies block growth signals of tumor cells, or induce apoptosis. Since the introduction of rituximab [61], 13 further tumor-directed antibodies have been approved.

Three of the most significant therapeutic approaches are represented by sipuleucel-T, an immunotherapeutic vaccine for prostate cancer [62]; ipilimumab, a check point inhibitor of CTLA-4 [63], and anti-programmed death receptor-1 (PD-1) and its ligand PDL-1 antibodies (anti-PD-1/PD-L-1) [64-66] for the treatment of metastatic melanoma.

Currently, cancer immunotherapies are classified as active and passive treatments. Active treatments include vaccines designed to induce tumor cell recognition. Passive treatments, on the other hand, imply direct administration of antibodies and T cells, to the patient. In this context, immune checkpoint inhibitors and adoptive $\mathrm{T}$ cell therapy are among the most innovative approaches [67]. At the clinical level, it is not yet clarified why certain patients respond to specific types of immunotherapies, while others do not. The development of future treatments depends on finding effective immune-based biomarkers that can help to predict responses to treatment.

\section{CONCLUDING REMARKS}

In this article, I have summarized the historical and experimental basis of tumor immune surveillance and cancer immunoediting (Figure 5) and I have discussed its dual roles in host protection and tumor escape. Many progresses have been found in this field starting from the original formulation of the immune surveillance theory, but further studies on cellular and molecular mechanisms to contribute to antitumor immune responses will be needed in the next years.

\section{ACKNOWLEDGMENTS}

This work was supported by European Union Seventh Framework Programme (FP7/2007-2013) under grant agreement n.278570 to DR.

\section{CONFLICTS OF INTEREST} interest.

The authors declare that there are no conflicts of

\section{REFERENCES}

1. Ehrlich P. Ueber den jetzigen Stand der Karzinomforschung. Ned Tijdschr Geneeskd. 1909; 5: 273-290.

2. Thomas L. Discussion of cellular and humoral aspects of hypersensitive states. Lawrence HS ed, New York, HoeberHarper, 1959.

3. Burnet FM, Cancer. A biological approach. 1. The process of control. Br Med J. 1957; 1: 779-782.

4. Gross L. Intradermal immunization of $\mathrm{C} 3 \mathrm{H}$ mice against a sarcoma that originated in an animal of the same line. Cancer Res. 1943; 3: 326-333.

5. Foley EJ. Antigenic properties of methylcholanthereneinduced tumors in mice of the strain of origin. Cancer Res. 1953; 13: 835-837.

6. Burnet FM. Immunological surveillance, Oxford, Pergamon Press 1970.

7. Clemente CG, Mihm MC Jr, Bufalino R, Zurrida S, Collini $\mathrm{P}$, Cascinelli N. Prognostic value of tumor infiltrating lymphocytes in the vertical growth phase of primary cutaneous melanoma. Cancer. 1996; 77: 1303-1310.

8. Rilke F, Colnaghi MI, Cascinelli N, Andreola S, Baldini MT, Bufalino R, Della Porta G, Ménard S, Pierotti MA, Testori A. Prognostic significance of HER-2/neu expression 
in breast cancer and its relationship to other prognostic factors. Int J Cancer. 1991; 49: 44-49.

9. Lipponen PK, Eskelinen MJ, Jauhiainen K, Harju E, Terho R. Tumour infiltrating lymphocytes as an independent prognostic factor in transitional cell bladder cancer. Eur J Cancer. 1992; 29A: 69-75.

10. Nacopoulou L, Azaris P, Papacharalampous N, Davaris P. Prognostic significance of histologic host response in cancer of the large bowel. Cancer. 1981; 47: 930-936.

11. Epstein NA, Fatti LP. Prostatic carcinoma: some morphological features affecting prognosis. Cancer. 1976; 37: 2455-2465.

12. Deligdisch L, Jacobs AJ, Cohen CJ. Histologic correlates of virulence in ovarian adenocarcinoma. II. Morphologic correlates of host response. Am J Obstet Gynecol. 1982; 144: 885-889.

13. Jass JR. Lymphocytic infiltration and survival in rectal cancer. J Clin Pathol. 1986; 39: 585-589.

14. Palma L, Di Lorenzo N, Guidetti B. Lymphocytic infiltrates in primary glioblastomas and recidivous gliomas. Incidence, fate, and relevance to prognosis in 228 operated cases. $\mathrm{J}$ Neurosurg 1978; 49: 854-861.

15. Waldhauer I, Steinle A. NK cells and cancer immunosurveillance. Oncogene. 2008;27: 932-943.

16. Nishikawa H, Sakaguchi S. Regulatory $\mathrm{T}$ cells in tumor immunity. Int J Cancer. 2010; 127: 759-767.

17. Facciabene A, Motz GT, Coukos G. T regulatory cells: key players in tumor immune escape and angiogenesis. Cancer Res. 2012; 72: 2162-2171.

18. Boon $\mathrm{T}$, van der Bruggen P. Human tumor antigens recognized by T lymphocytes. J Exp Med. 1996; 183: 725729.

19. Stutman O. Tumor development after 3-methylcholanthrene in immunologically deficient athymic-nude mice. Science. 1974;183: 534-536.

20. Outzen HC, Custer RP, Eaton GJ, Prehn RT. Spontaneous and induced tumor incidence in germfree "nude" mice. J Reticuloendothel Soc. 1975; 17: 1-9.

21. Kaplan DH, Shankaran V, Dighe AS, Stockert E, Aguet M, Old LJ, Schreiber RD. Demonstration of an interferon gamma-dependent tumor surveillance system in immunocompetent mice. Proc Natl Acad Sci USA. 1998; 95: 7556-7561.

22. Shankaran V, Ikeda H, Bruce AT, White JM, Swanson PE, Old LJ, Schreiber RD, IFN gamma and lymphocytes prevent primary tumour development and shape tumour immunogenicity. Nature 2001; 410: 1107-1111.

23. Dighe A, Richards E, Old L, Schreiber R. Enhanced in vivo growth and resistance to rejection of tumor cells expressing dominant negative IFN-receptors. Immunity. 1994; 1: 447456.

24. Gleave ME, Elhilali M, Fradet Y, Davis I, Venner P, Saad F, Klotz LH, Moore MJ, Paton V, Bajamonde A.Interferon $\gamma-1 \mathrm{~b}$ compared with placebo in metastatic renal-cell carcinoma. Canad Urolo Oncology Group. N. Engl. J. Med. 1998; 338: 1265-1271.

25. Wiesenfeld M, O'Connell MJ, Wieand HS, Gonchoroff NJ, Donohue JH, Fitzgibbons RJ Jr., Krook JE, Mailliard JA, Gerstner JB, Pazdur R. Controlled clinical trial of interferon- $\gamma$ as postoperative surgical adjuvant therapy for colon cancer. J Clin Oncol. 1995; 13:2324-2329.

26. Jett JR, Maksymiuk AW, Su JQ, Mailliard JA, Krook JE, Tschetter LK, Kardinal CG, Twito DI, Levitt R, Gerstner JB. Phase III trial of recombinant interferon $\gamma$ in complete responders with small-cell lung cancer. J Clin Oncol. 1994; 12: $2321-2326$.

27. van den Broek ME, Kägi D, Ossendorp F, Toes R, Vamvakas S, Lutz WK, Zinkernagel RM, Hengarten H. Decreased tumor surveillance in perforin-deficient mice. J Exp Med. 1996; 184: 1781-1790.

28. Bolitho P, Street SEA, Westwood JA, Edelmann W, MacGregor D, Waring P, Murray WK, Godfrey DI, Trapani JA, Johnstone RW, Smyth MJ. Perforin-mediated suppression of B-cell lymphoma. Proc Natl Acad Sci USA. 2009; 106: 2723-2728.

29. Street SE, Hayakawa Y, Zhan Y, Lew AM, MacGregor D, Jamieson AM, Diefenbach A, Yagita H, Godfrey DI, Smyth MJ. Innate immune surveillance of spontaneous B cell lymphomas by natural killer cells and gamma delta $\mathrm{T}$ cells. J Exp Med. 2004;199: 879-884.

30. Clementi R, Locatelli F, Dupré L, Garaventa A, Emmi L, Bregni M, Cefalo G, Moretta A, Danesino C, Comis M, Pession A, Ramenghi U, Maccario R, et al. A proportion of patients with lymphoma may harbor mutations of the perforin gene. Blood. 2005; 105: 4424-4428.

31. Melief CJM, Schwartz RS. Immunocompetence and malignancy, In Cancer: A Comprehensive treatise, Vol. 1, Becker FF Ed., New York, Plenum Press, 1975, pp. 121160.

32. Schulz TF. Cancer and viral infection in immunocompromised individuals. Int J Cancer. 2009; 125: 1755-1763.

33. Gaidano G, Dalla-Favera R. Biologic aspects of human immunodeficiency virus-related lymphoma. Curr Opin Oncol. 1992; 4: 900-906.

34. Ru-Chen M. Epstein-Barr virus, the immune system, and associated diseases. Front Microbiol 2011; 2: 5.

35. Mesri EA, Cesarman E, Arvanitakis L, Rafii S, Moore MA, Posnett DN, Knowles DM, Asch AS. Human herpes virus-8/Kaposi's sarcoma associated herpes virus is a new transmissible virus that infects B cells. J Exp Med 1996; 183: 2385-2390.

36. Tholey DM, Ahn J. Impact of hepatitis C virus infection on hepatocellular carcinoma. Gastroent Clin North Am. 2015; 44: 761-773.

37. Engels EA, Frisch M, Goedert JJ, Biggar RJ, Miller RW. Merkel cell carcinoma and HIV infection. Lancet 2002; 359: 497-498. 
38. Mc Farlane GA, Munro A. Helicobacter pylori and gastric cancer. Br J Surg. 1997; 84: 1190-1199.

39. Silva J, Cerqueira F, Medeiros R. Chlamydia trachomatis infection: implications for HPV status and cervical cancer. Arch Gynecol Obstet. 2014; 289: 715-723.

40. Morrissey D, O’Sullivan GC, Tangney M. Tumour targeting with systemically administered bacteria. Curr Gene Ther. 2010; 10: 3-14.

41. Toso JF. Phase I study of the intravenous administration of attenuated Salmonella typhi murium to patients with metastatic melanoma. J Clin Oncol. 2002; 20: 142-152.

42. Chapman JR, Webster AC, Wong G. Cancer in the transplant recipient. Cold Spring Harb Perspect. Med. 2013; 3: a015677.

43. Pawelec G, Derhov E, Larbi A. Immunosenescence and cancer. Crit Rev Oncol Hematol. 2010; 75: 165-172.

44. Fulop T, Kotb R, Fortin CF, Pawelec G, de Angelis F, Larbi A. Potential role of immunosenescence in cancer development. Ann N Y Acad Sci. 2010; 1197: 158-165.

45. Martinez C. Effect of early thymectomy on development of mammary tumours in mice. Nature 1964; 203: 1188.

46. Penn I. Tumors of the immunocompromised patient. Ann Rev Med. 1988; 39: 63-73.

47. Yunis EJ, Martinez C, Smith J, Stutman O, Good RA. Spontaneous mammary adenocarcinoma in mice: influence of thymectomy and reconstitution with thymus grafts or spleen cells. Cancer Res. 1969; 29: 174-178.

48. Stewart T, Tsai SC, Grayson H, Henderson R, Opelz G. Incidence of de-novo breast cancer in women chronically immunosuppressed after organ transplantation. Lancet. 1995; 346: 796-798.

49. Stutman O. Immunodepression and malignancy. Adv Cancer Res. 1975; 22: 261-422.

50. Sirvastava PK. Immunity to cancers, in Male D, Brostoff J, Roth DB, Roitss I, eds. Immunology, Seventh edition, Mosby Elsevier, 2006, pp. 422.

51. Dunn GP, Bruce AT, Ikeda H, Old LJ, Schreiber RD. Cancer immunoediting: from immunosurveillance to tumor escape. Nat Immunol. 2002; 3: 991-998.

52. Gasser S, Raulet DH. The DNA damage response arouses the immune system. Cancer Res. 2006; 66: 3959-3962.

53. Dhodapkar MV. Immune response to premalignancy: insights from patients with monoclonal gammopathy. Ann N Y Acad Sci. 2005; 1062: 22-28.

54. Dhodapkar MV, Krasovsky J, Osman K, Geller MD. Vigorous premalignancy-specific effector $\mathrm{T}$ cell response in the bone marrow of patients with monoclonal gammopathy. J Exp Med. 2003; 198: 1753-1757.

55. Corthay A. Does the immune system naturally protect against cancer? Front Immunol. 2014; 12: 197.

56. Teng MW, Galon J, Fridman WH, Smyth MJ. From mice to humans: developments in cancer immunoediting. J Clin Invest. 2015; 125: 3338-3346.
57. Muenst S, Läubli H, Soysal SD, Zippelius A, Tzankov A, Hoeller S. The immune system and cancer evasion strategies: therapeutic concepts. J Intern Med. 2016; 279: 541-562.

58. Dunn GP, Old LJ, Schreiber RD. The three Es of cancer immunoediting. Ann Rev Immunol. 2004; 22: 329-360.

59. Schwann JB, Smyth MJ. Immune surveillance of tumors. J Clin Invest 2007; 117: 1137-1146.

60. Ledford H. Cancer treatment: the killer within. Nature 2014;505: 24-26.

61. Cheson BD, Leonard JP. Monoclonal antibody therapy for B-cell non Hodgkin's lymphoma. N Engl J Med. 2008; 359 : 613-626.

62. Gulley JL, Mulders P, Albers P, Banchereau J, Bolla M, Pantel K, Powles P. Perspectives on sipuleucel-T: Its role in the prostate cancer treatment paradigm. Oncoimmunology. 2015; 10: e1107698.

63. Hodi FS, O’Day SJ, McDermott DF, Weber RW, Sosman JA, Haanen JB, Gonzalez R, Robert C, Schadendorf D, Hassel JC, Akerley W, van den Eertwegh AJ, Lutzky J, et al. Improved survival with ipilimumab in patients with metastatic melanoma. N Engl J Med. 2010; 363: 711-723.

64. He YF, Zhang GM, Wang XH, Zhang H, Yuan Y, Li D, Feng ZH. Blocking programmed death-1 ligand-PD-1 interactions by local gene therapy results in enhancement of antitumor effect of secondary lymphoid tissue chemokine. J Immunol. 2004;173: 4919-4928.

65. Blank C, Brown I, Peterson AC, Spiotto M, Iwai Y, Honjo T, Gajewski TF. PD-L1/B7H-1 inhibits the effector phase of tumor rejection by $\mathrm{T}$ cell receptor (TCR) transgenic CD8+ T cells. Cancer Res. 2004; 64: 1140-1145.

66. Philips GK, Atkins M. Therapeutic uses of anti-PD-1 and anti-PD-L1 antibodies. Int Immunol 2015; 27: 39-46.

67. Sharma P, Allison JP. The future of immune check point therapy. Science. 2015; 348: 56-61. 